\title{
FACTORS AFFECTING THE RISK OF POSTPARTUM DEPRESSION IN YOGYAKARTA
}

\author{
Sri Widarti',2), Uki Retno Budihastuti3), Vitri Widyaningsih4) \\ 1)Midwifery Academy of Nyai Ahmad Dahlan, Yogyakarta \\ 2)Masters Program in Public Health, Universitas Sebelas Maret \\ 3)Department of Obstetrics and Gynecology, Dr. Moewardi Hospital \\ 4)Faculty of Medicine, Universitas Sebelas Maret
}

\begin{abstract}
Background: Women are at risk of mental health problems during pregnancy and postnatal period in the immediate first year after delivery. Domestic violence is factors that lead women to develop postpartum depression. This study aimed to examine factors affecting the risk of postpartum depression in Yogyakarta, Indonesia.

Subjects and Method: This was a cross sectional study conducted at 30 villages in Yogyakarta, from March to April 2019. A sample of 210 postpartum mothers was selected by proportional random sampling. The dependent variable was postpartum depression. The independent variables were family support, domestic violence, stress, ANC visit, and income. Postpartum depression was measured by Endinburgh postnatal depression scale. Maternal stress was measured by Kessler psychological distress scale. The other variables were collected by questionnaire. The data were analyzed by a multiple linear regression.

Results: Strong family support $(b=-7.49 ; 95 \% \mathrm{CI}=-10.80$ to $-4.18 ; \mathrm{p}<0.001)$, ANC visit $\geq 4$ times $(b=-0.26 ; 95 \% \mathrm{CI}=-0.38$ to $-0.14 ; \mathrm{p}<0.001)$, and income $\geq \mathrm{Rp} 1,527,150$ $(\mathrm{b}=-3.32 ; 95 \% \mathrm{CI}=-4.56$ to -2.07 ; $\mathrm{p}<0.001)$ decreased post partum depression. Domestic violence $(b=5.91 ; 95 \% \mathrm{CI}=2.83$ to 8.88 ; $\mathrm{p}<0.001)$ and stress $(\mathrm{b}=0.25 ; 95 \% \mathrm{CI}=$ 0.17 to $0.33 ; \mathrm{p}<0.001)$ increased postpartum depression.

Conclusion: Strong family support, ANC visit $\geq 4$ times, and high income, decrease post partum depression. Domestic violence and stress increase postpartum depression.
\end{abstract}

Keywords: postpartum depression, domestic violence, antenatal care

\section{Correspondence:}

Sri Widarti. Masters Program in Public Health, Universitas Sebelas Maret. Jl. Ir. Sutami 36A, Surakarta 57126, Central Java. Email: widacorset@gmail.com. Mobile: o82135814923

The $6^{\text {th }}$ International Conference on Public Health Best Western Premier Hotel, Solo, Indonesia, October 23-24, 2019 | 159 